\title{
Effects of extruded linseed supplementation on n-3 fatty acids and conjugated linoleic acid in milk and cheese from ewes
}

\author{
P. Gómez-Cortés, ${ }^{*}$ A. Bach, †‡ P. Luna, ${ }^{*}$ M. Juárez, ${ }^{*}$ and M. A. de la Fuente ${ }^{* 1}$ \\ *Instituto del Frío (Consejo Superior de Investigaciones Científicas), Ciudad Universitaria s/n 28040 Madrid, Spain \\ †Institució Catalana de Recerca i Estudis Avançats, 08010 Barcelona, Spain \\ ¥Grup de Recerca en Nutrició, Maneig i Benestar Animal, Unitat de Remugants, Institut de Recerca i Tecnologia Agroalimentàries, Torre Marimon, \\ 08140 Caldes de Montbuí, Spain
}

\section{ABSTRACT}

The objective of this study was to assess the effects of dietary supplementation of extruded linseed on animal performance and fatty acid (FA) profile of ewe milk for the production of n-3 FA- and conjugated linoleic acid-enriched cheeses. A Manchega ewe flock (300 animals) receiving a 60:40 forage:concentrate diet was divided into 3 groups supplemented with 0,6 , and $12 \mathrm{~g}$ of extruded linseed/100 g of dry matter for the control, low, and high extruded linseed diets, respectively. Bulk and individual milk samples from 5 dairy ewes per group were monitored at 7, 14, 28, 45, and 60 $\mathrm{d}$ following supplementation. Manchego cheeses were made with bulk milk from the 3 treatment groups. Milk yield increased in dairy ewes receiving extruded linseed. Milk protein, fat, and total solids contents were not affected by linseed supplementation. Milk contents of $\alpha$-linolenic acid increased from 0.36 with the control diet to $1.91 \%$ total FA with the high extruded linseed diet. Similarly, cis-9 trans-11 C18:2 rose from 0.73 to $2.33 \%$ and its precursor in the mammary gland, trans-11 C18:1, increased from 1.55 to $5.76 \%$ of total FA. This pattern occurred with no significant modification of the levels of trans-10 C18:1 and trans-10 cis-12 C18:2 FA. Furthermore, the high extruded linseed diet reduced C12:0 (-30\%), C14:0 (-15\%) and C16:0 (-28\%), thus significantly diminishing the atherogenicity index of milk. The response to linseed supplementation was persistently maintained during the entire study. Acceptability attributes of n-3-enriched versus control cheeses ripened for 3 mo were not affected. Therefore, extruded linseed supplementation seems a plausible strategy to improve animal performance and nutritional quality of dairy lipids in milk and cheese from ewes.

Key words: n-3 fatty acid, cheese, ewe, extruded linseed

Received November 18, 2008.

Accepted June 2, 2009.

${ }^{1}$ Corresponding author: mafl@if.csic.es

\section{INTRODUCTION}

The ratio of saturated fatty acids (SFA) to polyunsaturated fatty acids (PUFA) in dairy fat has generally been regarded as undesirable from a human nutrition perspective because of a probable link between dietary medium-chain saturated fatty acids (C12:0, C14:0, and C16:0), serum cholesterol, and heart disease. Milk fat contains more than $60 \%$ of SFA, 20 to $25 \%$ of monounsaturated fatty acids, about $5 \%$ of PUFA, less than $0.5 \%$ of n-3 fatty acid ( $\alpha$-linolenic), and minor compounds potentially linked to specific health promoting properties, such as rumenic acid (RA, cis-9 trans-11 C18:2, Bauman et al., 2006), the most biologically active conjugated linoleic acid (CLA) isomer.

Recently, there has been a growing interest in what is referred to as the functional food aspect of milk fat. This involves designing milk fat to improve its healthy and functional properties for human consumption. One strategy could be to reduce C12:0, C14:0, and C16:0 milk contents because of their potential hypercholesterolemic effects, and to substantially increase the content of $\alpha$-linolenic acid as well as other potentially healthy fatty acids (FA). Because of the transfer into milk of part of the dietary $\alpha$-linoleic acid, the inclusion of linseed in the diet has been shown to increase the $\alpha$-linolenic and CLA contents in milk from cows (Collomb et al., 2004; Akraim et al., 2007; Da Silva et al., 2007) and ewes (Luna et al., 2005, 2008a; Zhang et al., 2006; Mele et al., 2007). However, increases of milk $\alpha$-linolenic acid have been modest except for in one study (Mele et al., 2007). Increasing the level of $\alpha$-linolenic acid in milk from ruminants seems difficult because of the relatively low transfer rate of this FA from the diet into milk (Palmquist, 2006; Sanz-Sampelayo et al., 2007) and the dietary inclusion constraints necessary to avoid negative effects on rumen fermentation and milk yield (Deaville et al., 2004; Gonthier et al., 2005).

The objective of this study was to evaluate the effects of dietary supplementation of extruded linseed on animal performance and its long-term sustainability and 
Table 1. Ingredient and nutrient composition of control, low (LEL), and high (HEL) extruded linseed experimental diets

\begin{tabular}{|c|c|c|c|}
\hline \multirow[b]{2}{*}{ Item } & \multicolumn{3}{|c|}{ Dietary treatment } \\
\hline & Control & LEL & HEL \\
\hline \multicolumn{4}{|l|}{ Ingredients, $\%$ of DM } \\
\hline Alfalfa hay & 35.5 & 34.8 & 34.7 \\
\hline Beet pulp & 5.1 & 5.0 & 5.0 \\
\hline Corn & 4.2 & 4.1 & 4.1 \\
\hline Soybean meal & 8.6 & 8.4 & 6.7 \\
\hline Barley & 11.4 & 11.1 & 4.3 \\
\hline Corn distillers dried grains & 10.8 & 10.6 & 10.6 \\
\hline Wheat straw & 17.3 & 16.9 & 16.9 \\
\hline Green peas & 3.4 & - & - \\
\hline Corn gluten feed & 0.9 & - & - \\
\hline Malt sprouts & 0.9 & - & - \\
\hline Sunflower meal & 0.4 & 1.3 & 2.6 \\
\hline Palm oil & 0.1 & - & - \\
\hline Calcium soaps of palm fatty acids & 0.9 & - & - \\
\hline Linseed & - & 6.0 & 12.0 \\
\hline Wheat middlings & - & 1.3 & 2.6 \\
\hline Sodium chloride & 0.5 & 0.4 & 0.4 \\
\hline Mineral-vitamin premix & 0.1 & 0.1 & 0.1 \\
\hline \multicolumn{4}{|l|}{ Nutrients } \\
\hline $\mathrm{CP}, \%$ & 18.3 & 18.3 & 18.2 \\
\hline $\mathrm{NDF}, \%$ & 43.2 & 43.6 & 41.7 \\
\hline $\mathrm{ADF}, \%$ & 29.6 & 29.8 & 28.9 \\
\hline Ether extract, \% & 3.3 & 5.3 & 7.0 \\
\hline $\mathrm{NE}_{\mathrm{L}}, \mathrm{Mcal} / \mathrm{kg}$ & 1.60 & 1.69 & 1.81 \\
\hline NFC, $\%$ & 29.3 & 27.6 & 28.9 \\
\hline Lauric acid, \% & 0.03 & 0.03 & 0.03 \\
\hline Myristic acid, \% & 0.04 & 0.04 & 0.04 \\
\hline Palmitic acid, \% & 0.67 & 0.44 & 0.56 \\
\hline Palmitoleic acid, \% & 0.03 & 0.05 & 0.06 \\
\hline Stearic acid, $\%$ & 0.09 & 0.15 & 0.26 \\
\hline Oleic acid, \% & 0.71 & 0.83 & 1.28 \\
\hline Linoleic acid, \% & 0.97 & 1.15 & 1.39 \\
\hline$\alpha$-Linolenic acid, \% & 0.29 & 1.39 & 2.43 \\
\hline Eicosanoic acid, \% & 0.07 & 0.08 & 0.10 \\
\hline
\end{tabular}

on the production of CLA- and n-3 FA-enriched cheese from ewe milk.

\section{MATERIALS AND METHODS}

All animals were handled following the guidelines of the Animal Care Committee of IRTA (Institut de Recerca i Tecnologia Agroalimentàries).

\section{Animals and Dietary Treatments}

A total of 300 milking Manchega ewes in early lactation (DIM at the beginning of the study $=8 \pm 5$ d), distributed in 3 separate groups of 100 ewes with each group divided into 5 pens (20 ewes in each), were used in this study. Three different treatments were assayed for a period of $60 \mathrm{~d}$. Throughout the experiment, 5 pens received a typical milking ration with a forage:concentrate ratio of 60:40 (control), 5 pens were supplemented with 6\% (DM basis) of extruded linseed (low extruded linseed, LEL), and 5 pens were supple- mented with $12 \%$ (DM basis) of extruded linseed (high extruded linseed, HEL). Diet composition is described in Table 1.

\section{Sampling}

Bulk milk and 5 individual milk samples from 5 animals randomly chosen from each treatment were collected at $7,14,28,45$, and $60 \mathrm{~d}$ from the beginning of the study. Individual milk production was also recorded at these time points. All samples were obtained during the morning milking. Thus, a total of 15 bulk milk samples and 75 total individual milk samples were generated and subsequently analyzed to determine FA profile by gas chromatography. Bulk milk samples were also used to determine the effects of linseed supplementation on CLA isomeric profile of milk fat by $\mathrm{Ag}^{+}-\mathrm{HPLC}$. Finally, individual milk samples were used to determine milk chemical composition.

\section{Cheesemaking and Cheese Sensory Analyses}

Bulk milk from 3 separate bulk tanks (one per treatment) at $45 \mathrm{~d}$ from the start of the experiment was used for the manufacture of cheeses. A set of Manchego cheeses from each treatment (control, LEL, and HEL) was manufactured on the same day according to the process of the Protected Denomination Origin regulatory board (Luna et al., 2008a). Three cheeses from each set were sampled and tested on the same day at $90 \mathrm{~d}$ of ripening. A wedge (1-cm thick) was cut from the block of cheese and the rind was removed. A sensory test was conducted following IDF recommendations (IDF, 1987) by a trained group of panelists (used to consuming this type of cheese) and consisting of staff (30 tasters) from the Instituto del Frío (Madrid, Spain). Cheeses from the different milks were randomized when presented to the panel for testing. The attributes analyzed were appearance, aroma, taste, texture, and general acceptability. All analyses were rated on a 10-point scale (degree of liking): $0=$ unfit for human consumption, $1-2=$ very poor conformity with the preestablished sensory standard, $3-4=$ poor conformity, $5-6=$ fair conformity, $7-8$ $=$ good conformity, and $9-10=$ very good conformity.

\section{Analytical Methods}

All ingredients in the diet were analyzed for DM (24 $\mathrm{h}$ at $\left.103^{\circ} \mathrm{C}\right)$, ash $\left(4 \mathrm{~h}\right.$ at $\left.550^{\circ} \mathrm{C}\right), \mathrm{N}$ content (AOAC, 1990), ether extract (AOAC, 1990), and neutral and acid detergent fibers (Van Soest et al., 1991). Fatty acids of the dietary components were analyzed and quantified as described by Luna et al. (2008b). Fat, lactose, protein, and total solids in milk were measured 
with a MilkoScan FT-6000 (Foss Electric, Barcelona, Spain). Total solids and fat in cheeses were determined according to Luna et al. (2008a).

Milk and cheese fats were extracted as described by Luna et al. (2008a). Fatty acid methyl esters (FAME) were prepared by base-catalyzed methanolysis of the glycerides (KOH in methanol). Analysis of FAME was performed on a gas-liquid chromatograph (Agilent 6890 N Network System, Agilent Technologies, Santa Clara, CA) onto a CP-Sil 88 fused silica capillary column (100 $\mathrm{m} \times 0.25 \mathrm{~mm}$, Varian, Middelburg, the Netherlands) under the conditions reported by Luna et al. (2008a).

Quantification of individual FAME by reference to a milk fat with known composition (CRM 164; European Community Bureau of Reference, Brussels, Belgium) was performed according to ISO-IDF (2002). Individual CLA isomers were identified by comparison to standards distributed by Nu-Chek Prep (Elysian, MN). A mixture of FA from Nu-Chek (GLC-461) was also used to identify other FA, whereas cis-9 trans-11 cis-15 C18:3 (rumelenic acid, CLnA) standard was generously provided by P. Angers, Université Laval, Canada.

Separation of CLA methyl esters was achieved by $\mathrm{Ag}^{+}$-HPLC using a Shimadzu HPLC apparatus (model SPE-MA10AVP, Kyoto, Japan) equipped with a diode array detector operated at $233 \mathrm{~nm}$ at $29^{\circ} \mathrm{C}$. Three ChromSpher 5 Lipids analytical silver-impregnated columns $(250 \mathrm{~mm} \times 4.6 \mathrm{~mm}$ i.d. stainless steel; $5 \mu \mathrm{m}$ particle size; Varian) were used in series. A fresh mixture of acetonitrile $(0.1 \%)$ and diethyl ether $(0.5 \%)$ in hexane was used to elute the CLA isomers at a flow rate of $1 \mathrm{~mL} / \mathrm{min}$. Because a reliable internal standard for CLA is not yet available, data were referred to gas chromatography results. The sum $\mathrm{Ag}^{+}$-HPLC areas for 7-9, 8-10, and 9-11 positional isomers (cis-trans plus trans-cis) were used for comparison with the peak area of these 3 isomers obtained from the gas chromatogram. The amounts of the remaining CLA isomers were calculated from their $\mathrm{Ag}^{+}$-HPLC areas relative to the area of the main isomer 9-11 as described by Collomb et al. (2004).

\section{Statistical Analysis}

Performance and milk composition data were analyzed using a mixed-effects model with repeated measures using SAS (SAS Inst. Inc., Cary, NC). The model accounted for the fixed effects of dietary treatment, time, and the interaction between treatment and time, plus the random effects of sheep and pen. The data included in the model were derived from the 5 individual sheep plus the bulk milk from each treatment and the model used weights to emphasize the relevance of the bulk milk relative to the individual milk samples.
Time was considered a repeated factor, and for each analyzed variable, animal nested within treatment (the error term) was subjected to a compound symmetry variance-covariance structure.

Data referring to cheese composition and sensory evaluation of cheeses were analyzed using a one-way ANOVA with dietary treatment as the only factor in the model. Statistical significance was declared at $P \leq$ 0.05 .

\section{RESULTS}

Milk fat, protein, lactose, and total solids contents were not modified by dietary treatments (Table 2). However, numerically, both milk protein and fat content were decreased by 9 and $6 \%$ with the HEL treatment compared with control, respectively. Milk fat and protein contents were affected $(P<0.01)$ and total solids tended $(P=0.06)$ to be affected by the stage of lactation (Table 2$)$. Milk yield was greatest $(P<0.05)$ for ewes fed LEL and HEL relative to those fed the control diet.

All groups of FA were modified by lipid supplementation (Table 3). Dietary inclusion of extruded linseed reduced proportions of SFA with $<18$ carbons in milk, except for butyric acid. For example, the milk percentages of C12:0, C14:0, and C16:0 FA diminished $(P<$ 0.01 ) between 15 and 30\% with LEL and HEL diets compared with control. Feeding supplemented with linseed to ewes also diminished $(P<0.01)$ the percentage of the odd-chain (C13:0, C15:0, and C17:0) and most of the branched-chain FA (C13:0 anteiso, C14:0 iso, C15:0 iso, C15:0 anteiso, and C16:0 iso) in milk fat. On the contrary, milk levels of most 18-carbon FA increased $(P<0.05)$ with extruded linseed supplementation (Table 3). Milk contents of stearic acid and oleic acid (cis-9 C18:1) were greatest in ewes fed linseedenriched rations, but they were not influenced by the level of supplementation. Additionally, other cis and most of the trans C18:1 isomers rose as a consequence of dietary supplementation of extruded linseed. Milk vaccenic acid (VA, trans-11 C18:1) content increased $(P<0.05)$ more than 3 -fold with the HEL diet. Milk percentages of other trans C18:1 isomers were also enhanced with linseed supplementation, but increments were minor compared with VA.

Although LEL and HEL rations did not result in changes of linoleic acid (cis-9 cis-12 C18:2) percentage in milk fat, remarkable increases of other C18:2 isomers were observed. Among nonconjugated C18:2 molecules, the greatest corresponded to the trans-11 cis-15 C18:2 isomer. In the current study, RA milk content followed a similar trend to VA, with a 2- to 3-fold increase when extruded linseed was supplemented. Apart from RA, 
Table 2. Milk production and chemical composition of milk from ewes fed diets supplemented with 0 (control), 6 (low extruded linseed; LEL), and 12 (high extruded linseed; HEL) g of extruded linseed/100 g of $\mathrm{DM}^{1}$

\begin{tabular}{|c|c|c|c|c|c|c|c|}
\hline \multirow[b]{2}{*}{ Item } & \multicolumn{3}{|c|}{ Treatment } & \multirow[b]{2}{*}{ SEM } & \multicolumn{3}{|c|}{$P$-value ${ }^{2}$} \\
\hline & Control & LEL & HEL & & $\mathrm{D}$ & $\mathrm{T}$ & $\mathrm{D} \times \mathrm{T}$ \\
\hline Fat & $34.17^{\mathrm{b}}$ & $54.01^{\mathrm{a}}$ & $50.80^{\mathrm{a}}$ & 4.751 & 0.03 & 0.77 & 0.10 \\
\hline Protein & $31.13^{\mathrm{b}}$ & $48.75^{\mathrm{a}}$ & $44.12^{\mathrm{a}}$ & 4.136 & 0.03 & 1.00 & 0.11 \\
\hline Lactose & $26.26^{\mathrm{b}}$ & $46.12^{\mathrm{a}}$ & $41.20^{\mathrm{a}}$ & 3.912 & $<0.01$ & 0.56 & 0.14 \\
\hline Fat & 6.51 & 6.10 & 6.12 & 0.386 & 0.71 & 0.34 & 0.13 \\
\hline Protein & 5.89 & 5.38 & 5.36 & 0.181 & 0.11 & $<0.01$ & 0.15 \\
\hline Lactose & 4.91 & 5.05 & 5.01 & 0.079 & 0.47 & $<0.01$ & 0.79 \\
\hline Total solids & 17.97 & 17.25 & 17.20 & 0.444 & 0.41 & 0.06 & 0.10 \\
\hline
\end{tabular}

${ }^{\mathrm{a}, \mathrm{b}}$ Means within a row with different superscripts differ $(P<0.05)$.

${ }^{1}$ Data correspond to the analysis of milk from 5 ewes within each treatment collected over a 2-mo period.

${ }^{2}$ Effects caused by dietary treatment $(\mathrm{D})$, time on diet $(\mathrm{T})$, and their interaction $(\mathrm{D} \times \mathrm{T})$.

other conjugated C18:2 isomers were also found in milk (Table 3). The results from $\mathrm{Ag}^{+}-\mathrm{HPLC}$ indicate that a high supplementation of $\alpha$-linolenic acid (HEL) leads to an increased production of trans-11 cis-13, trans-11 trans-13, cis-12 trans-14, trans-12 trans-14, and trans-9 trans-11 C18:2 (Figure 1). In contrast, extruded linseed supplementation had minimal effects on trans-10 cis-12 and trans-9 cis-11 C18:2 in milk fat.

The proportion of $\alpha$-linolenic acid in milk increased 3.5- and 5.3-fold with LEL and HEL diets, respectively. Furthermore, linseed supplementation was accompanied by increases $(P<0.01)$ in CLnA, a conjugated isomer of $\alpha$-linolenic acid. The effect of LEL and HEL diets on $\alpha$-linolenic and most of the medium-chain SFA persisted throughout the 2-mo treatment period (Figure 2). Rumenic acid and VA levels were also sustained throughout the study. Furthermore, levels of trans-10 C18:1 in milk from ewes receiving the LEL and HEL diets did not differ from those found with the control diet and were stable for the 2 mo of study.

Most of the eicosenoic and docosenoic FA were detected at very low percentages in all milk samples (Table 3). Arachidonic acid (20:4 n-6) was the PUFA present in milk at the greatest concentration. Eicosenoic and docosenoic n-3 PUFA (C20:3, C20:5, C22:5, and C22:6) concentrations in milk fat were always below $0.10 \%$. Overall, these results showed that extruded linseed supplementation substantially diminished $(P<0.01)$ the percentage of SFA and increased $(P<0.01)$ the monounsaturated FA and PUFA contents, thus contributing to the modification of saturated:unsaturated FA ratio and decreasing $(P<0.01)$ the atherogenicity index of milk.

Table 4 depicts the FA profile of cheeses made from 3 different types of raw milk after 3 mo of ripening.
These FA profiles did not substantially differ from those observed in raw milk fat. Levels of RA, and mainly $\alpha$-linolenic acid, were greater in LEL and HEL than in control cheeses, whereas atherogenicity index and n-6/n-3 ratio in HEL were lower $(P<0.01)$ than in control and LEL cheeses. Moreover, all cheeses were positively evaluated for appearance, aroma, taste, and texture, and the scores assigned by trained panelist to cheese for overall quality did not differ across treatments (Table 5).

\section{DISCUSSION}

\section{Milk Yield and Composition}

The increase in milk production observed when feeding the rations containing extruded linseed could be attributed to the greater energy supply of these rations compared with the unsupplemented one (Table 1). This increase in milk yield would explain, in part, the greater $(P<0.05)$ fat, protein, lactose, and total solid yields (Table 2). Although the effects of unprotected dietary lipid supplementation of ewes on milk protein and fat contents reported in the literature are variable, the lack of decrease in milk fat content observed in the current study is in agreement with most of the previous results conducted with sheep (Pulina et al., 2006; Sanz-Sampelayo et al., 2007). The extent of this effect depends, among other factors, on the type of supplemented fat, the level at which it is included in the ration, the state of lactation, the fiber and fat digestibilities, and the dietary forage:concentrate ratio. For instance, supplementing unprotected lipids to ewes receiving a high concentrate ration $(>60 \%$ of $\mathrm{DM})$ resulted in a negative effect on milk fat content (SanzSampelayo et al., 2007). 
Table 3. Fatty acid profile (g/100 g of total fatty acid methyl esters) of milk fat from ewes fed a diet supplemented with 0 (control), 6 (low extruded linseed; LEL), and 12 (high extruded linseed; HEL) $\mathrm{g}$ of extruded linseed/100 $\mathrm{g}$ of $\mathrm{DM}^{1}$

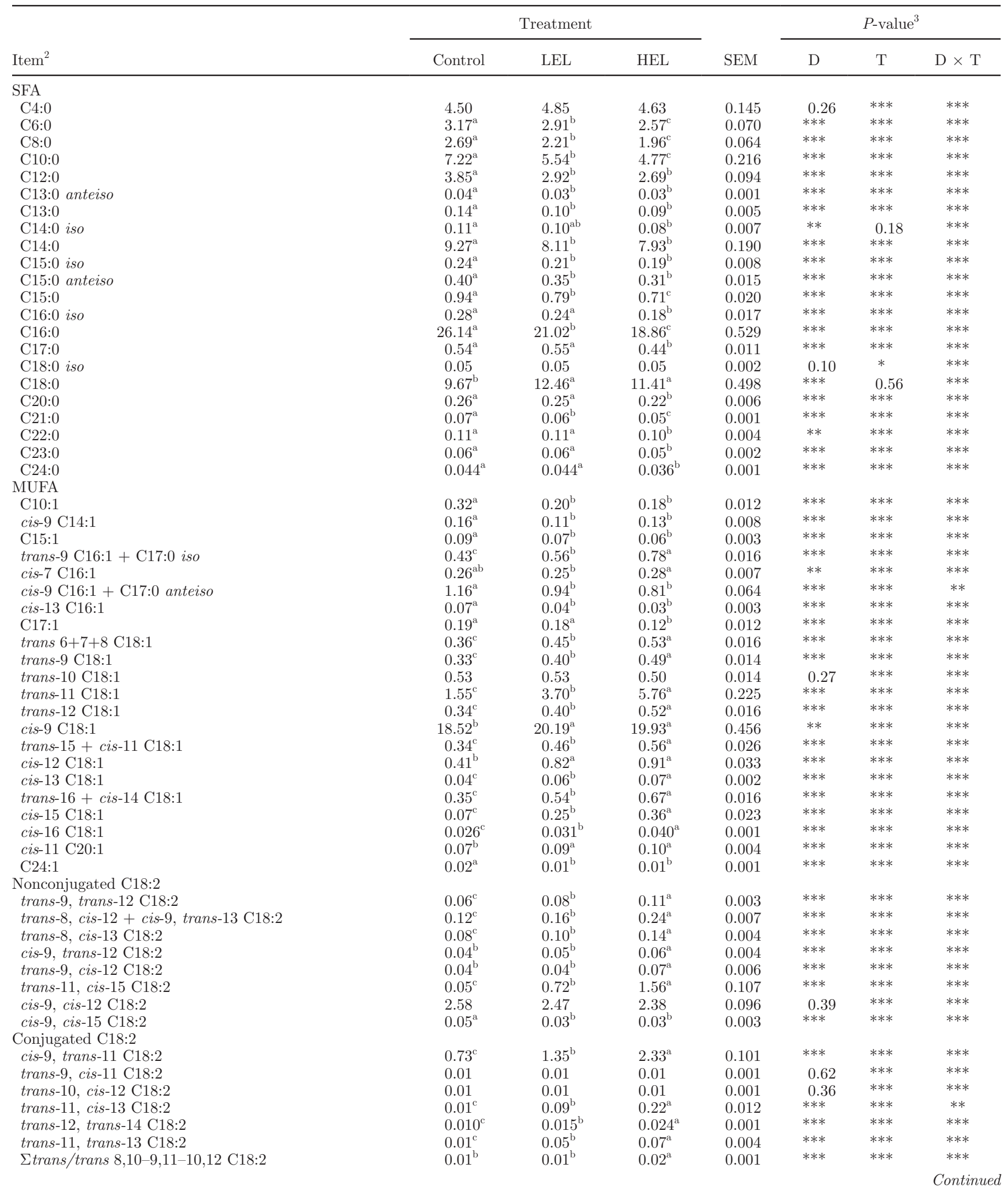


Table 3 (Continued). Fatty acid profile ( $\mathrm{g} / 100 \mathrm{~g}$ of total fatty acid methyl esters) of milk fat from ewes fed a diet supplemented with 0 (control), 6 (low extruded linseed; LEL), and 12 (high extruded linseed; HEL) g of extruded linseed/100 g of DM ${ }^{1}$

\begin{tabular}{|c|c|c|c|c|c|c|c|}
\hline Item $^{2}$ & \multicolumn{3}{|c|}{ Treatment } & SEM & \multicolumn{3}{|c|}{$P$-value ${ }^{3}$} \\
\hline \multicolumn{8}{|l|}{ Other PUFA } \\
\hline cis-9, cis-12, cis-15 C18:3 & $0.36^{\mathrm{c}}$ & $1.27^{\mathrm{b}}$ & $1.91^{\mathrm{a}}$ & 0.109 & $* * *$ & $* * *$ & $* * *$ \\
\hline cis-9, trans-11, cis-15 C18:3 & $0.04^{\mathrm{c}}$ & $0.14^{\mathrm{b}}$ & $0.29^{\mathrm{a}}$ & 0.015 & $* * *$ & $* *$ & $* * *$ \\
\hline $\mathrm{C} 20: 2$ & 0.02 & 0.02 & 0.02 & 0.001 & 0.35 & $* *$ & *** \\
\hline $\mathrm{C} 20: 4 \mathrm{n}-6$ & $0.16^{\mathrm{a}}$ & $0.12^{\mathrm{b}}$ & $0.10^{\mathrm{c}}$ & 0.004 & $* * *$ & $* * *$ & $* * *$ \\
\hline $\mathrm{C} 20: 5 \mathrm{n}-3$ & $0.02^{\mathrm{b}}$ & $0.04^{\mathrm{a}}$ & $0.04^{\mathrm{a}}$ & 0.002 & $* * *$ & $* * *$ & $* * *$ \\
\hline $\mathrm{C} 22: 2$ & $0.01^{\mathrm{c}}$ & $0.03^{\mathrm{b}}$ & $0.04^{\mathrm{a}}$ & 0.001 & $* * *$ & $* * *$ & *** \\
\hline $\mathrm{C} 22: 4 \mathrm{n}-6$ & $0.02^{\mathrm{a}}$ & $0.01^{\mathrm{b}}$ & $0.01^{\mathrm{b}}$ & 0.001 & $* * *$ & $* * *$ & $* * *$ \\
\hline $\mathrm{C} 22: 5 \mathrm{n}-3$ & $0.06^{\mathrm{b}}$ & $0.08^{\mathrm{a}}$ & $0.08^{\mathrm{a}}$ & 0.007 & $*$ & $* * *$ & $* * *$ \\
\hline $\mathrm{C} 22: 6 \mathrm{n}-3$ & 0.03 & 0.03 & 0.03 & 0.002 & 0.84 & $* * *$ & $* * *$ \\
\hline$\Sigma \mathrm{SFA}$ & $69.81^{\mathrm{a}}$ & $63.24^{\mathrm{b}}$ & $57.16^{\mathrm{c}}$ & 0.893 & $* * *$ & $* * *$ & $* * *$ \\
\hline
\end{tabular}

${ }^{\mathrm{a}-\mathrm{c}}$ Means within a row with different superscripts differ $(P<0.05)$.

${ }^{1}$ Values represent the mean from 5 individual animals plus bulk milk from 100 ewes.

${ }^{2} \mathrm{MUFA}=$ monounsaturated fatty acid; PUFA $=$ polyunsaturated fatty acid; SFA $=$ saturated fatty acid.

${ }^{3}$ Effects caused by dietary treatment $(\mathrm{D})$, time on $\operatorname{diet}(\mathrm{T})$, and their interaction $(\mathrm{D} \times \mathrm{T})$.

${ }^{4}$ Atherogenicity index: $(\mathrm{C} 12: 0+4 \times \mathrm{C} 14: 0+\mathrm{C} 16: 0) /(\mathrm{MUFA}+\mathrm{PUFA})$.

${ }^{*} P<0.10 ; * * P<0.05 ; * * * P<0.01$.

\section{SFA}

The diversity of milk FA arises from the effects of ruminal biohydrogenation of dietary unsaturated FA and the de novo FA synthesis in the mammary gland. Results from the current research support previous evidence (Loor et al., 2004) that feeding unsaturated lipids or oils to ruminants usually reduces the odd-chain and most of the branched-chain FA in milk fat (Table 3). This effect could be related to a direct inhibition of dietary unsaturated FA on rumen microbial odd-chain and branched-chain FA synthesis, which could result in reduced flows to the intestine or a dilution effect because of an overall greater supply of PUFA.

Fatty acids from C6:0 to C14:0 are synthesized de novo in the mammary gland, whereas $\mathrm{C} 16: 0$ is derived from both diet and de novo synthesis. A substantial part of the reduction in de novo synthesis of FA as a result of feeding PUFA (Table 3) could be due to an increased uptake of dietary and ruminally derived FA. These unsaturated FA compete for esterification with short- and medium-chain FA synthesized in the mammary gland. The accumulation of such FA may lead to feedback inhibition of lipogenic enzymes (Palmquist, 2006). The lack of change in butyric acid in milk samples when increasing dietary linseed supplementation (Table 3) could be attributed to the existence of an alterna- tive anabolic pathway independent of the condensation of acetyl units in the mammary gland via acetyl-CoA carboxylase.

\section{n-3 PUFA}

Despite the low transfer efficiency of n-3 FA from diet to milk fat, levels of $\alpha$-linolenic acid in milk achieved with the HEL treatment (nearly $2 \%$ ) are among the greatest found in the literature. Previous studies have reported increases in $\alpha$-linolenic acid below 3-fold (Luna et al., 2005, 2008a; Zhang et al., 2006; Mele et al., 2007). The magnitude of the increase observed in the present study (Table 3 ) could be primarily attributed to the quantity of linseed added to the rations. Proportions of linseed below 2\% DM on ewe diets (Luna et al., 2005, 2008a) barely doubled the contents of $\alpha$-linolenic acid in milk fat. In addition, the form of the oilseed in the ration is most likely another factor responsible for the observed increase in $\alpha$-linolenic acid in milk. Supplementation with $6.7 \%$ of whole linseed in the diet of lactating sheep resulted only in a 2-fold increase in the secretion of $\alpha$-linolenic acid in milk (Zhang et al., 2006). However, the supplementation of extruded linseed resulted in more than 2-fold increase of $\alpha$-linolenic acid in milk from both ewes (Mele et al., 2007) and cows (Akraim et al., 2007). Physical breakdown of linseed by extru- 

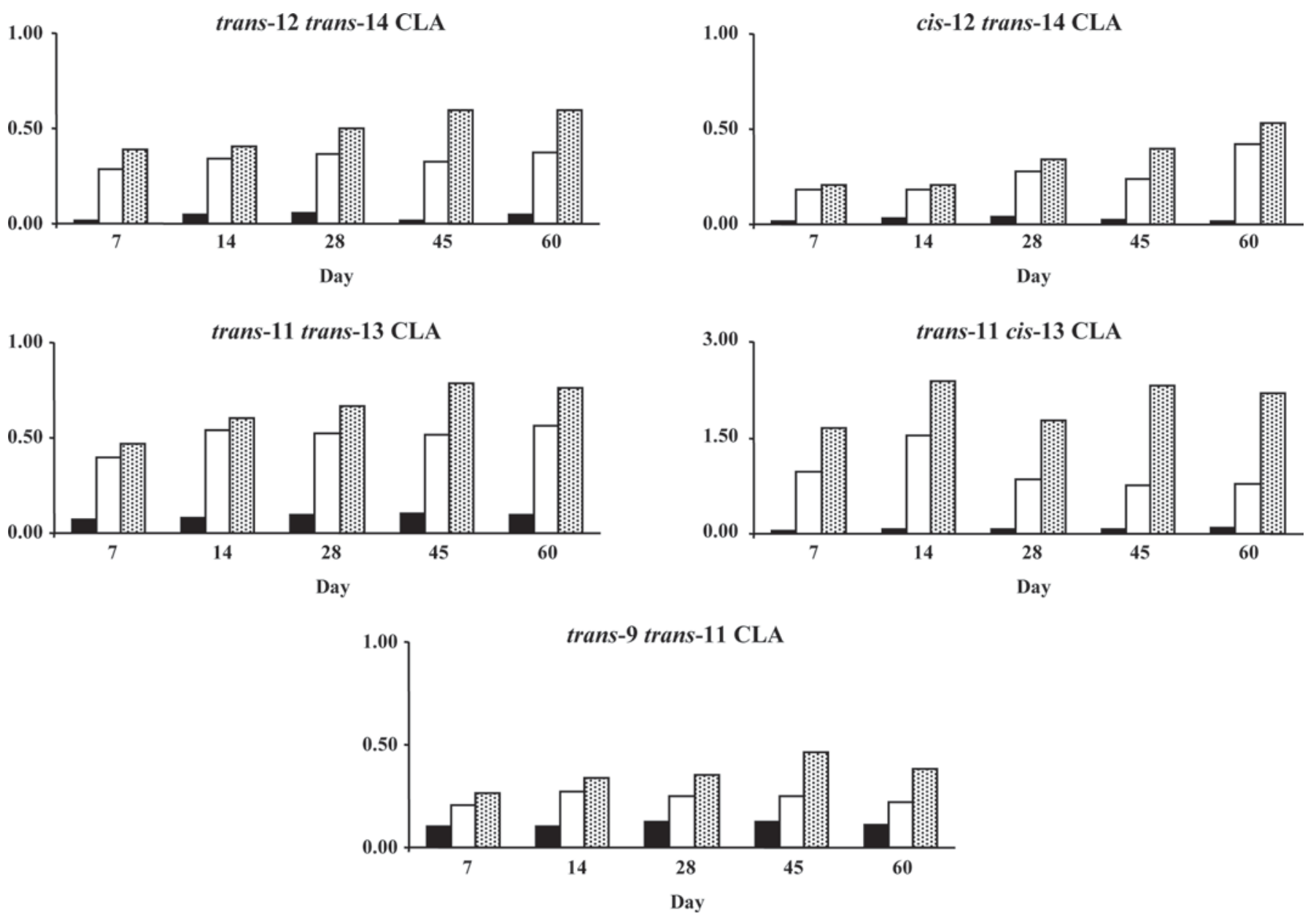

Figure 1. Concentration (mg/g of total fatty acid methyl esters) of trans-12 trans-14, cis-12 trans-14, trans-11 trans-13, trans-11 cis-13, and trans-9 trans-11 conjugated linoleic acid (CLA) isomers determined by silver ion HPLC in bulk milk fat from ewes fed a diet supplemented with 0 (black bar), 6 (white bar), and 12 (gray bar) g of extruded linseed/100 g of DM.

sion may contribute to enhancing the availability of $\alpha$-linolenic acid for absorption in the digestive tract, which would, in turn, result in an increased concentration in milk.

The very low milk contents of other n-3 long PUFA observed in the current study are in line with those reported in cows supplemented with different proportions of linseed (Collomb et al., 2004) or linseed oil (Loor et al., 2005a; Bu et al., 2007). The marked decrease of the n-6:n-3 FA ratio (Table 3) in the LEL and HEL groups compared with the control could be attributed to the presence of high levels of $\alpha$-linolenic acid in the supplemented diets. Increases in 20:5 and 22:5 n-3 in conjunction with the decreases of cis-6 cis-9 cis-12 C18:3, 20:3, 20:4, and 22:4 n-6 FA would indicate that a high consumption of $\alpha$-linolenic acid could displace the physiological equilibrium between n- 6 and n-3 metabolic pathways, generating more long-chain n-3 FA.

\section{Biohydrogenation Intermediates}

The increased milk levels of stearic acid with linseed supplementation should be attributed to the biohydrogenation of dietary PUFA in the rumen. Stearic acid could then be subsequently converted into cis-9 C18:1 in the mammary gland via $\Delta^{9}$-desaturase, contributing to increase the contents of oleic acid in ewe milk fat (Table 3).

The main pathway for rumen biohydrogenation of a-linolenic acid (cis-9 cis-12 cis-15 C18:3) involves an initial isomerization to CLnA followed by a reduction of double bonds at carbons 9,15 , and 11 to yield trans-11 cis-15 C18:2, VA, and finally C18:0 (Wilde and Dawson, 1966). Pearson correlations between these FA were 0.91 $(\alpha$-linolenic acid vs. CLnA), 0.95 ( $\alpha$-linolenic acid vs. trans-11 cis-15 C18:2), 0.82 ( $\alpha$-linolenic acid vs. VA), 0.94 (CLnA vs. trans-11 cis-15 C18:2), 0.91 (CLnA vs. 


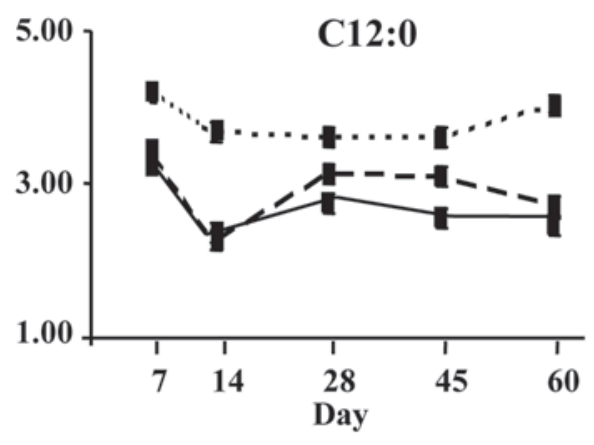

C14:0
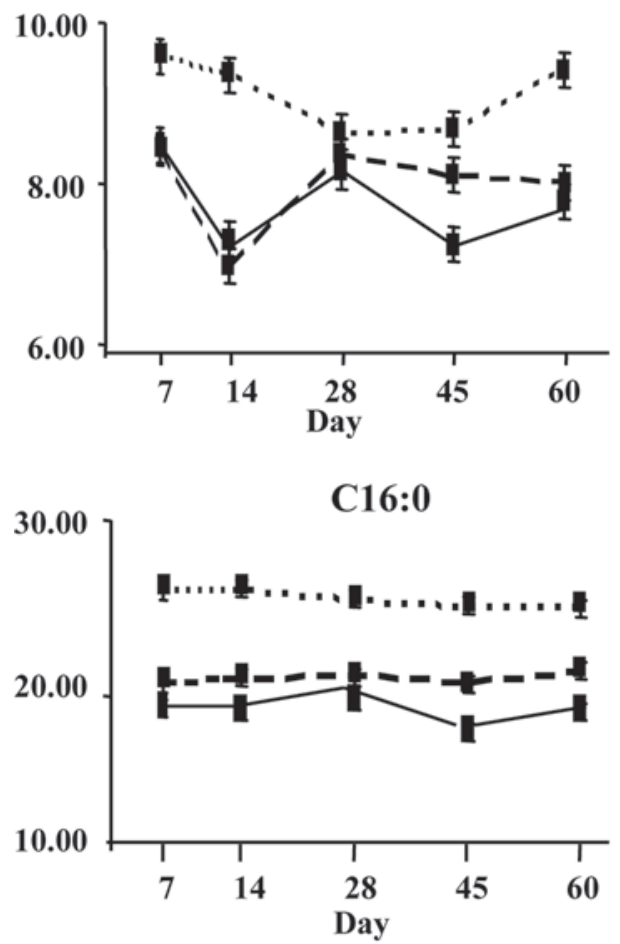

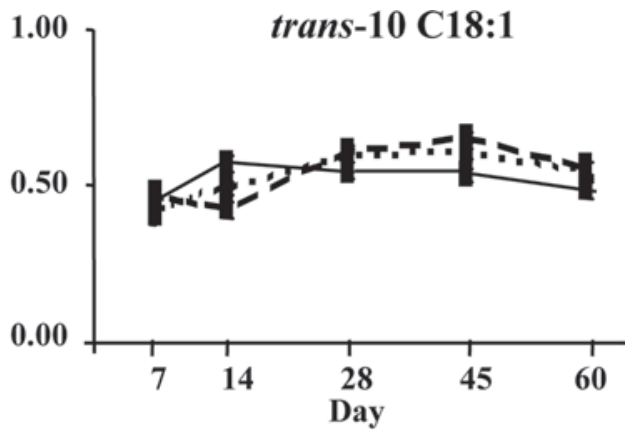

trans-11 C18:1
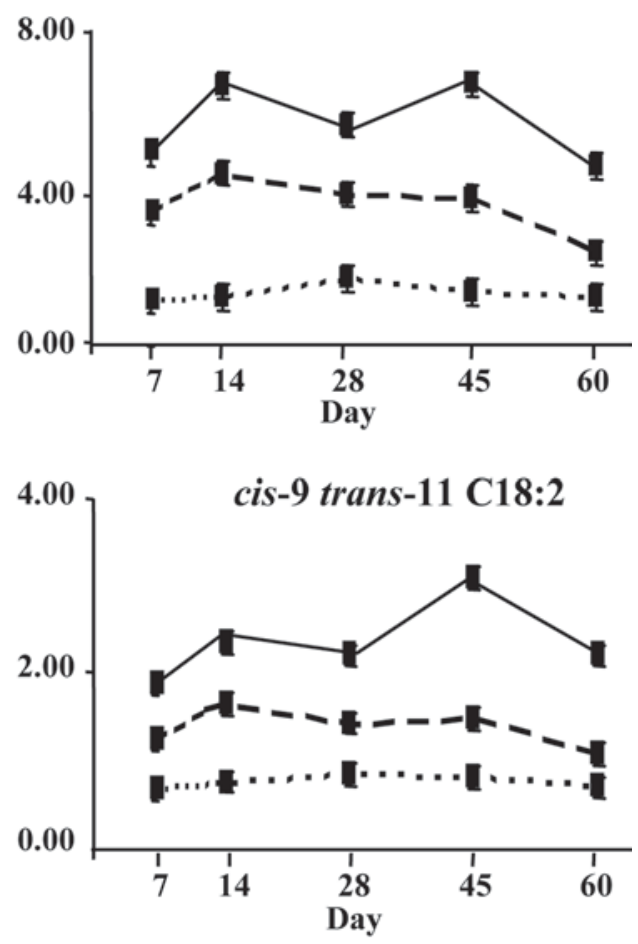

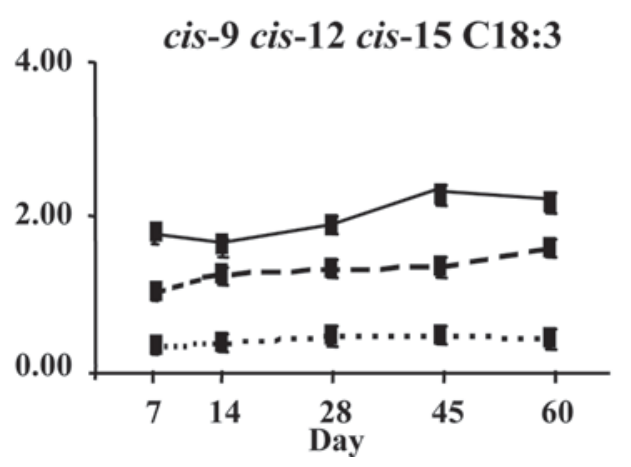

Figure 2. Evolution of C12:0, C14:0, C16:0, trans-10 C18:1, trans-11 C18:1, cis-9 trans-11 C18:2, and cis-9 cis-12 cis-15 C18:3 content (g/100 $\mathrm{g}$ of total fatty acid methyl esters) in milk fat from ewes fed a diet supplemented with 0 (dotted line), 6 (dashed line), and 12 (solid line) $\mathrm{g}$ of extruded linseed/100 g of DM. Values represent the mean from 5 individual animals plus bulk milk from 100 ewes 
Table 4. Fatty acid profile ( $\mathrm{g} / 100 \mathrm{~g}$ of total fatty acid methyl esters) of cheeses made with raw milk from ewes fed a diet supplemented with 0 (control), 6 (low extruded linseed; LEL), and 12 (high extruded linseed; HEL) $\mathrm{g}$ of extruded linseed/100 g of DM, after $90 \mathrm{~d}$ of ripening

\begin{tabular}{|c|c|c|c|c|c|}
\hline \multirow[b]{2}{*}{ Item $^{1}$} & \multicolumn{3}{|c|}{ Treatment } & \multirow[b]{2}{*}{ SEM } & \multirow[b]{2}{*}{$P$-value } \\
\hline & Control & LEL & HEL & & \\
\hline \multicolumn{6}{|l|}{ SFA } \\
\hline $\mathrm{C} 4: 0$ & $3.77^{\mathrm{c}}$ & $4.04^{\mathrm{b}}$ & $4.31^{\mathrm{a}}$ & 0.050 & *** \\
\hline C6:0 & $2.94^{\mathrm{a}}$ & $2.85^{\mathrm{b}}$ & $2.62^{\mathrm{c}}$ & 0.020 & $* * *$ \\
\hline $\mathrm{C} 8: 0$ & $2.64^{\mathrm{a}}$ & $2.41^{\mathrm{b}}$ & $2.04^{\mathrm{c}}$ & 0.011 & $* * *$ \\
\hline C10:0 & $7.35^{\mathrm{a}}$ & $6.19^{\mathrm{b}}$ & $5.06^{\mathrm{c}}$ & 0.024 & $* * *$ \\
\hline $\mathrm{C} 12: 0$ & $4.07^{\mathrm{a}}$ & $3.32^{\mathrm{b}}$ & $2.83^{\mathrm{c}}$ & 0.017 & $* * *$ \\
\hline $\mathrm{C} 13: 0$ anteiso & $0.05^{\mathrm{a}}$ & $0.03^{\mathrm{b}}$ & $0.02^{\mathrm{b}}$ & 0.003 & $* * *$ \\
\hline C13:0 & $0.15^{\mathrm{a}}$ & $0.11^{\mathrm{b}}$ & $0.09^{c}$ & 0.002 & $* * *$ \\
\hline $\mathrm{C} 14: 0$ iso & $0.10^{\mathrm{a}}$ & $0.09^{\mathrm{b}}$ & $0.09^{\mathrm{b}}$ & 0.002 & $* *$ \\
\hline $\mathrm{C} 14: 0$ & $9.23^{\mathrm{a}}$ & $8.49^{\mathrm{b}}$ & $7.87^{\mathrm{c}}$ & 0.023 & $* * *$ \\
\hline $\mathrm{C} 15: 0$ iso & $0.24^{\mathrm{a}}$ & $0.23^{\mathrm{b}}$ & $0.22^{\mathrm{c}}$ & 0.002 & $* * *$ \\
\hline $\mathrm{C} 15: 0$ anteiso & $0.38^{\mathrm{a}}$ & $0.35^{\mathrm{b}}$ & $0.32^{\mathrm{c}}$ & 0.002 & $* * *$ \\
\hline C15:0 & $0.91^{\mathrm{a}}$ & $0.83^{\mathrm{b}}$ & $0.76^{\mathrm{c}}$ & 0.003 & *** \\
\hline C16:0 iso & $0.28^{\mathrm{a}}$ & $0.23^{\mathrm{b}}$ & $0.20^{\mathrm{c}}$ & 0.004 & $* * *$ \\
\hline C16:0 & $25.20^{\mathrm{a}}$ & $20.79^{\mathrm{b}}$ & $18.33^{\mathrm{c}}$ & 0.060 & $* * *$ \\
\hline $\mathrm{C} 17: 0$ & $0.55^{\mathrm{a}}$ & $0.53^{\mathrm{a}}$ & $0.48^{\mathrm{b}}$ & 0.007 & *** \\
\hline C18:0 iso & $0.06^{\mathrm{a}}$ & $0.04^{\mathrm{b}}$ & $0.07^{\mathrm{a}}$ & 0.004 & $* * *$ \\
\hline C18:0 & $10.22^{\mathrm{b}}$ & $13.31^{\mathrm{a}}$ & $13.56^{\mathrm{a}}$ & 0.086 & $* * *$ \\
\hline $\mathrm{C} 20: 0$ & $0.26^{\mathrm{ab}}$ & $0.27^{\mathrm{a}}$ & $0.25^{\mathrm{b}}$ & 0.005 & $*$ \\
\hline C21:0 & $0.06^{\mathrm{a}}$ & $0.05^{\mathrm{a}}$ & $0.03^{\mathrm{b}}$ & 0.003 & $* * *$ \\
\hline $\mathrm{C} 22: 0$ & $0.15^{\mathrm{a}}$ & $0.15^{\mathrm{a}}$ & $0.14^{\mathrm{b}}$ & 0.002 & $* * *$ \\
\hline $\mathrm{C} 23: 0$ & 0.06 & 0.07 & 0.06 & 0.004 & 0.17 \\
\hline $\mathrm{C} 24: 0$ & 0.05 & 0.05 & 0.05 & 0.002 & 0.42 \\
\hline \multicolumn{6}{|l|}{ MUFA } \\
\hline C10:1 & $0.35^{\mathrm{a}}$ & $0.22^{\mathrm{b}}$ & $0.19^{\mathrm{c}}$ & 0.003 & $* * *$ \\
\hline cis-9 C14:1 & $0.17^{\mathrm{a}}$ & $0.10^{\mathrm{b}}$ & $0.10^{\mathrm{b}}$ & 0.002 & $* * *$ \\
\hline C15:1 & $0.07^{\mathrm{ab}}$ & $0.07^{\mathrm{a}}$ & $0.06^{\mathrm{b}}$ & 0.003 & 0.10 \\
\hline trans-9 C16:1 + C17:0 iso & $0.45^{\mathrm{c}}$ & $0.57^{\mathrm{b}}$ & $0.68^{\mathrm{a}}$ & 0.004 & $* * *$ \\
\hline cis-7 C16:1 & 0.25 & 0.23 & 0.24 & 0.006 & 0.31 \\
\hline cis-9 C16:1 + C17:0 anteiso & $1.22^{\mathrm{a}}$ & $0.78^{\mathrm{b}}$ & $0.71^{\mathrm{c}}$ & 0.007 & $* * *$ \\
\hline cis-13 C16:1 & $0.08^{\mathrm{a}}$ & $0.04^{\mathrm{b}}$ & $0.03^{\mathrm{c}}$ & 0.002 & $* * *$ \\
\hline $\mathrm{C} 17: 1$ & $0.20^{\mathrm{a}}$ & $0.14^{\mathrm{b}}$ & $0.13^{\mathrm{c}}$ & 0.003 & *** \\
\hline trans $6+7+8 \mathrm{C} 18: 1$ & $0.34^{\mathrm{c}}$ & $0.46^{\mathrm{b}}$ & $0.53^{\mathrm{a}}$ & 0.005 & $* * *$ \\
\hline trans $-9 \mathrm{C} 18: 1$ & $0.33^{\mathrm{c}}$ & $0.39^{\mathrm{b}}$ & $0.46^{\mathrm{a}}$ & 0.004 & $* * *$ \\
\hline trans-10 C18:1 & 0.49 & 0.48 & 0.50 & 0.009 & 0.45 \\
\hline trans-11 C18:1 & $1.68^{\mathrm{c}}$ & $3.79^{\mathrm{b}}$ & $5.25^{\mathrm{a}}$ & 0.009 & $* * *$ \\
\hline trans-12 C18:1 & $0.31^{\mathrm{c}}$ & $0.42^{\mathrm{b}}$ & $0.50^{\mathrm{a}}$ & 0.013 & $* * *$ \\
\hline cis-9 C18:1 & $19.26^{\mathrm{b}}$ & $18.63^{\mathrm{c}}$ & $19.61^{\mathrm{a}}$ & 0.039 & $* * *$ \\
\hline trans- $15+$ cis-11 C18:1 & $0.29^{\mathrm{c}}$ & $0.44^{\mathrm{b}}$ & $0.54^{\mathrm{a}}$ & 0.011 & $* * *$ \\
\hline cis-12 C18:1 & $0.40^{\mathrm{c}}$ & $0.75^{\mathrm{b}}$ & $0.91^{\mathrm{a}}$ & 0.004 & $* * *$ \\
\hline cis-13 C18:1 & $0.05^{\mathrm{b}}$ & $0.07^{\mathrm{a}}$ & $0.07^{\mathrm{a}}$ & 0.003 & $* *$ \\
\hline trans- $16+$ cis-14 C18:1 & $0.39^{\mathrm{c}}$ & $0.60^{\mathrm{b}}$ & $0.74^{\mathrm{a}}$ & 0.014 & *** \\
\hline cis-15 C18:1 & $0.09^{\mathrm{c}}$ & $0.27^{\mathrm{b}}$ & $0.41^{\mathrm{a}}$ & 0.013 & $* * *$ \\
\hline cis-16 C18:1 & $0.03^{\mathrm{c}}$ & $0.04^{\mathrm{b}}$ & $0.05^{\mathrm{a}}$ & 0.002 & *** \\
\hline cis-11 C20:1 & $0.08^{\mathrm{b}}$ & $0.10^{\mathrm{a}}$ & $0.10^{\mathrm{a}}$ & 0.003 & $* * *$ \\
\hline $\mathrm{C} 24: 1$ & 0.02 & 0.02 & 0.01 & 0.003 & 0.73 \\
\hline \multicolumn{6}{|l|}{ Nonconjugated C18:2 } \\
\hline trans -9, trans-12 C18:2 & 0.07 & 0.08 & 0.08 & 0.009 & 0.72 \\
\hline trans- 8, cis- $12+$ cis- 9, trans- 13 C18:2 & $0.14^{\mathrm{b}}$ & $0.16^{\mathrm{b}}$ & $0.20^{\mathrm{a}}$ & 0.008 & $* *$ \\
\hline trans-8, cis-13 C18:2 & $0.09^{\mathrm{c}}$ & $0.11^{\mathrm{b}}$ & $0.14^{\mathrm{a}}$ & 0.005 & $* * *$ \\
\hline cis- 9 , trans-12 C18:2 & 0.05 & 0.04 & 0.05 & 0.003 & 0.22 \\
\hline trans- 9 , cis-12 C18:2 & $0.03^{\mathrm{b}}$ & $0.04^{\mathrm{b}}$ & $0.07^{\mathrm{a}}$ & 0.004 & $* * *$ \\
\hline trans-11, cis-15 C18:2 & $0.13^{\mathrm{b}}$ & $0.77^{\mathrm{b}}$ & $1.28^{\mathrm{a}}$ & 0.004 & $* * *$ \\
\hline cis-9, cis-12 C18:2 & 2.28 & 2.28 & 2.28 & 0.016 & 0.96 \\
\hline cis-9, cis-15 C18:2 & $0.08^{\mathrm{a}}$ & $0.04^{\mathrm{b}}$ & $0.03^{\mathrm{b}}$ & 0.005 & $* * *$ \\
\hline \multicolumn{6}{|l|}{ Conjugated C18:2 } \\
\hline cis-9, trans-11 C18:2 & $0.79^{\mathrm{c}}$ & $1.32^{\mathrm{b}}$ & $1.85^{\mathrm{a}}$ & 0.005 & $* * *$ \\
\hline trans -9, cis-11 C18:2 & 0.02 & 0.01 & 0.02 & 0.004 & 0.42 \\
\hline trans-10, cis-12 C18:2 & 0.01 & 0.01 & 0.01 & 0.001 & 0.99 \\
\hline trans-11, cis-13 C18:2 & $0.02^{\mathrm{c}}$ & $0.09^{\mathrm{b}}$ & $0.18^{\mathrm{a}}$ & 0.003 & $* * *$ \\
\hline trans-12, trans-14 C18:2 & $0.01^{\mathrm{b}}$ & $0.02^{\mathrm{a}}$ & $0.02^{\mathrm{a}}$ & 0.002 & $* * *$ \\
\hline trans -11, trans -13 C18:2 & $0.02^{\mathrm{c}}$ & $0.05^{\mathrm{b}}$ & $0.06^{\mathrm{a}}$ & 0.002 & $* * *$ \\
\hline Etrans/trans $8,10-9,11-10,12$ C18:2 & 0.02 & 0.02 & 0.02 & 0.002 & 0.42 \\
\hline
\end{tabular}


Table 4 (Continued). Fatty acid profile (g/100 g of total fatty acid methyl esters) of cheeses made with raw milk from ewes fed a diet supplemented with 0 (control), 6 (low extruded linseed; LEL), and 12 (high extruded linseed; HEL) g of extruded linseed/100 g of DM, after $90 \mathrm{~d}$ of ripening

\begin{tabular}{|c|c|c|c|c|c|}
\hline \multirow[b]{2}{*}{ Item $^{1}$} & \multicolumn{3}{|c|}{ Treatment } & \multirow[b]{2}{*}{ SEM } & \multirow[b]{2}{*}{$P$-value } \\
\hline & Control & LEL & HEL & & \\
\hline \multicolumn{6}{|l|}{ Other PUFA } \\
\hline cis- 6, cis-9, cis-12 C18:3 & $0.05^{\mathrm{a}}$ & $0.03^{\mathrm{b}}$ & $0.02^{\mathrm{b}}$ & 0.004 & $* * *$ \\
\hline cis-9, cis-12, cis-15 C18:3 & $0.46^{\mathrm{c}}$ & $1.33^{\mathrm{b}}$ & $1.77^{\mathrm{a}}$ & 0.005 & $* * *$ \\
\hline cis-9, trans- 11, cis-15 C18:3 & $0.04^{\mathrm{c}}$ & $0.15^{\mathrm{b}}$ & $0.23^{\mathrm{a}}$ & 0.001 & $* * *$ \\
\hline $\mathrm{C} 20: 2$ & 0.02 & 0.02 & 0.02 & 0.001 & 0.99 \\
\hline $\mathrm{C} 20: 3 \mathrm{n}-6$ & 0.01 & 0.01 & 0.01 & 0.003 & 0.30 \\
\hline C20:3 n-3 & 0.01 & 0.01 & 0.01 & 0.002 & 0.42 \\
\hline $\mathrm{C} 20: 4 \mathrm{n}-6$ & $0.16^{\mathrm{a}}$ & $0.11^{\mathrm{b}}$ & $0.10^{\mathrm{c}}$ & 0.002 & $* * *$ \\
\hline $\mathrm{C} 20: 5 \mathrm{n}-3$ & $0.03^{\mathrm{b}}$ & $0.05^{\mathrm{a}}$ & $0.05^{\mathrm{a}}$ & 0.001 & $* * *$ \\
\hline $\mathrm{C} 22: 2$ & $0.02^{\mathrm{a}}$ & $0.01^{\mathrm{b}}$ & $0.01^{\mathrm{b}}$ & 0.002 & $* *$ \\
\hline $\mathrm{C} 22: 4 \mathrm{n}-6$ & 0.02 & 0.01 & 0.01 & 0.003 & 0.22 \\
\hline $\mathrm{C} 22: 5 \mathrm{n}-3$ & $0.07^{\mathrm{b}}$ & $0.08^{\mathrm{ab}}$ & $0.08^{\mathrm{a}}$ & 0.003 & $* *$ \\
\hline $\mathrm{C} 22: 6 \mathrm{n}-3$ & 0.03 & 0.03 & 0.03 & 0.006 & 0.91 \\
\hline$\Sigma \mathrm{SFA}$ & $68.75^{\mathrm{a}}$ & $64.45^{\mathrm{b}}$ & $59.42^{\mathrm{c}}$ & 0.112 & $* * *$ \\
\hline इMUFA & $26.54^{\mathrm{c}}$ & $28.60^{\mathrm{b}}$ & $31.81^{\mathrm{a}}$ & 0.085 & *** \\
\hline इPUFA & $4.69^{\mathrm{c}}$ & $6.93^{\mathrm{b}}$ & $8.75^{\mathrm{a}}$ & 0.043 & $* * *$ \\
\hline Atherogenicity index ${ }^{2}$ & $2.12^{\mathrm{a}}$ & $1.63^{\mathrm{b}}$ & $1.30^{\mathrm{c}}$ & 0.009 & $* * *$ \\
\hline$n-6 / n-3$ & $3.97^{\mathrm{a}}$ & $1.49^{\mathrm{b}}$ & $1.12^{\mathrm{c}}$ & 0.019 & $* * *$ \\
\hline
\end{tabular}

${ }^{\mathrm{a}-\mathrm{c}}$ Means within a row with different superscripts differ $(P<0.05)$.

${ }^{1} \mathrm{MUFA}=$ monounsaturated fatty acid; PUFA $=$ polyunsaturated fatty acid; SFA = saturated fatty acid.

${ }^{2}$ Atherogenicity index: $(\mathrm{C} 12: 0+4 \times \mathrm{C} 14: 0+\mathrm{C} 16: 0) /($ MUFA + PUFA $)$.

${ }^{*} P<0.10 ;{ }^{* *} P<0.05 ;{ }^{* * *} P<0.01$.

VA), and 0.91 (trans-11 cis-15 C18:2 vs. VA). Therefore, confirming a high association between these compounds and the ruminal metabolism of cis-9 cis-12 cis-15 C18:3. To our knowledge, this is the first evidence of the presence in ewe milk fat of CLnA, formerly characterized by Destaillats et al. (2005) and more recently reported by Akraim et al. (2007) in cows consuming diets with high amounts of extruded linseed.

Milk contents of cis-15 C18:1 and cis-11 + trans-15 C18:1 isomers, which are considered to be important products from $\alpha$-linolenic acid biohydrogenation in cow milk (Loor et al., 2004, 2005a; Akraim et al., 2007), increased with the LEL and HEL treatments. The relative increase was greater for cis-15 than for trans-15 C18:1, which is consistent with the large amounts of trans-11 cis-15 C18:2 (Table 3). Milk content of cis-12 C18:1 also responded positively to extruded linseed supplementation $(P<0.01)$ as described previously with cows (Collomb et al., 2004; Loor et al., 2005b; Bell et al., 2006). Noticeable increases of cis-12 C18:1 have been reported in ruminal fluid when supplementing lipid sources rich in linoleic or $\alpha$-linolenic acids (Loor et al., 2004, 2005a). The lack of a noticeable increase in trans-10 C18:1 when supplementing linseed in the current study is particularly remarkable because this FA has been potentially associated with the risk of cardiovascular disease in humans (Bauman et al., 2006; Chardigny et al., 2008). The main reasons of this lack of increase in the current study may be linked to the source of lipid supplementation as well as the high dietary forage:concentrate ratio

Table 5. Mean scores and standard deviations of sensory attributes on a 10-point scale (degree of liking) for cheeses manufactured with raw milk from ewes fed a diet supplemented with 0 (control), 6 (low extruded linseed, LEL), and 12 (high extruded linseed, HEL) g of extruded linseed/100 g of DM ${ }^{1}$

\begin{tabular}{|c|c|c|c|c|c|}
\hline \multirow[b]{2}{*}{ Attribute } & \multicolumn{3}{|c|}{ Treatment } & \multirow[b]{2}{*}{ SEM } & \multirow[b]{2}{*}{$P$-value ${ }^{2}$} \\
\hline & Control & LEL & HEL & & \\
\hline Appearance & 7.32 & 7.37 & 7.27 & 0.224 & 0.95 \\
\hline Aroma & 7.06 & 6.47 & 6.74 & 0.246 & 0.24 \\
\hline Taste & 7.03 & 6.74 & 6.87 & 0.275 & 0.76 \\
\hline Texture & 6.89 & 6.71 & 6.82 & 0.293 & 0.91 \\
\hline General acceptability & 7.21 & 6.87 & 6.97 & 0.222 & 0.54 \\
\hline
\end{tabular}


used herein. Milk contents of trans-10 C18:1 have been reported to increase in cows (Bauman et al., 2006) and ewes (Gómez-Cortés et al., 2008; Hervás et al., 2008) when supplementing a source of linoleic acid to rations with a low forage:concentrate ratio.

\section{Conjugated Linoleic Acid}

Milk RA content increased more than 3-fold with HEL (reaching almost 2.5\%) compared with the control diet. The strong correlation between VA and RA observed in ewe milk fat in the present study $\left(\mathrm{R}^{2}=\right.$ $0.87)$ reflects the substrate:product relationship for $\Delta^{9}$ desaturase. These data confirm previous observations (Luna et al., 2005, 2008a; Nudda et al., 2005) that RA and VA in ewe milk fat are directly related. Most of the RA acid in milk originates from endogenous synthesis in mammary gland from VA via $\Delta^{9}$-desaturase. Because $\alpha$-linolenic acid biohydrogenation does not generate RA as an intermediate, the secretion of high concentrations of this CLA isomer in milk could only be achieved when high levels of VA are produced in the rumen (Bauman et al., 2006). The elevation in the RA contents observed in the present study was clearly greater than previously reported with ewes fed linseed supplements (Luna et al., 2005, 2008a; Zhang et al., 2006). As discussed above for $\alpha$-linolenic, the increase in milk RA content should also be attributed to the levels and physical form of dietary linseed. The process of extrusion could improve the accessibility of $\alpha$-linolenic acid to rumen microbiota. Thus, it can be hypothesized that if rumen biohydrogenation of this FA is increased, greater amounts of VA could be generated in the rumen and later converted to RA in the mammary gland. Mele et al. (2007) reported similar improvements in VA and RA proportions in milk fat to those of the current study with ewes fed extruded linseed.

In addition, LEL and HEL treatments also elevated the amounts of other CLA isomers in milk fat compared with control. The observed increases in trans-trans as well as trans-cis 11-13 CLA would be consistent with the increase of these compounds reported in duodenal flow and milk fat when supplementing linseed oil to dairy cows (Loor et al., 2004, 2005a,b). These FA could be formed by isomerization of trans-11 cis-15 C18:2 following pathways still unknown. On the other hand, a supply of high $\alpha$-linolenic acid along with a relatively high dietary forage:concentrate ratio (HEL and LEL rations) did not have a great potential to increase trans-10 cis-12 and trans-9 cis-11 C18:2 in milk fat. Previous studies in cows (Loor et al., 2005a,b; Bell et al., 2006) and ewes (Gómez-Cortés et al., 2008; Hervás et al., 2008) have indicated that the increase in trans-10 cis-12 and trans-9 cis-11 C18:2 in milk would be due to a change in rumen biohydrogenation elicited by the presence of linoleic acid when low-forage rations are fed.

\section{Persistency of the Response to Lipid Supplementation}

The persistency of the response to the lipid supplementation on milk FA profile reported herein is original, on the one hand, because only a few studies have reported sustained $(>28$ d) effects of dietary lipid supplementation on ewe milk FA profile (Luna et al., 2005; Mele et al., 2007); and on the other hand because the enrichment of RA in ewe milk fat could be transient because of the biohydrogenation shift toward trans-10 C18:1 and trans-10 cis-12 C18:2, as previously observed in some production studies (Gómez-Cortés et al., 2008; Hervás et al., 2008). The present results support the hypothesis that, under the assayed conditions, minimal shifts toward the trans-10 C18:1 rumen biohydrogenation pathway occurred. Differences in dietary forage:concentrate ratio as well as the inclusion level of linoleic acid between the current study and others (Gómez-Cortés et al., 2008; Hervás et al., 2008) could explain the different response. The effect of LEL and HEL treatments on milk contents of $\alpha$-linolenic and most of the medium-chain SFA also persisted throughout the 2-mo treatment period (Figure 2). Thus, the healthier milk FA profile obtained in this study was held for a relatively long period, which should facilitate commercial exploitation of this type of milk.

\section{Cheese Composition}

The effect of cheese manufacturing on FA profile was minor compared with the effects obtained with dietary treatments. These results coincide with most of the previous research on different kinds of ewes' milk cheeses (Luna et al., 2005, 2008a; Nudda et al., 2005). According to the recommendations of the European Food Safety Authority (EFSA), a food qualified as an "omega-3 FA source" must contain more than $15 \%$ per $100 \mathrm{~g}$ of product of the recommended n-3 FA daily consumption for an adult, whereas a product labeled as "high in omega-3 FA" should supply $\geq 30 \%$ of the EFSA daily consumption recommendation (EFSA, 2005). Because $2 \mathrm{~g} / \mathrm{d}$ is the recommended adult consumption of n-3 FA (EFSA, 2005) and the fat content of Manchego cheese is around $39.5 \%$, milk from ewes fed diets supplemented with extruded linseed similar to the ones of this study could be utilized to produce cheeses with improved nutritional properties. The contents of $\alpha$-linolenic acid in Manchego cheeses made from n-3 FA-enriched milks were 1.33 (LEL) and 1.77 (HEL) g/100 g of total FA 
(Table 4). Consequently, these cheeses could be classified as a "source of" (LEL) or "high in" (HEL) n-3 FA under current EFSA regulations.

General nutritional guidelines aiming at the reduction of the incidence of cardiovascular diseases have advocated for a decreased intake of SFA and trans FA. In this regard, changes obtained in the FA profile of cheeses in the current study could also be considered beneficial for the consumer. For instance, the atherogenicity index in HEL was lower $(P<0.01)$ than in control and LEL cheeses. However, concerning cheese contents of trans C18:1, the lowest levels of this FA were found in the cheeses from the control treatment, and this would represent the best option from a nutritional point of view. However, increasing evidence suggests that trans FA isomers from ruminant fats differ in their relationship to the risk of human coronary heart diseases. This difference is related specifically to the position of trans double bond (Bauman et al., 2006; Chardigny et al., 2008). Most of the available data examining variables associated with cardiovascular pathologies in humans are related to trans FA from partially hydrogenated vegetable oils, commonly enriched in trans-9 and trans-10 C18:1, whereas VA is the predominant isomer in dairy fat. Furthermore, RA, and its precursor in the ruminant mammary gland, VA, could have anticarcinogenic activity when supplied as natural food components (Bauman et al., 2006). The functional food considerations of CLA isomers in dairy products relate to RA as the major isomer, although this should include VA, because in humans it acts as a precursor for the endogenous synthesis of RA (Bauman et al., 2006).

The overall hedonic rating (6.9 to 7.2) of the experimental cheeses confirmed that cheeses from all treatments were liked by panelists, indicating that the increase in PUFA contents in cheeses from ewes receiving the supplemented diets was acceptable and comparable to cheeses manufactured using milk from unsupplemented ewes. These results confirm those observed in previous studies where improvements in n-3 FA and CLA contents in ewe milk had no detrimental consequences on organoleptic characteristics of ewe cheeses (Luna et al., 2005, 2008a; Sinclair et al., 2007).

\section{CONCLUSIONS}

Dietary extruded linseed supplementation has minimal repercussions on milk fat and protein composition but markedly influences the FA profile of milk fat from ewes. The addition, in extruded form, of 6 and $12 \mathrm{~g}$ of linseed $/ 100 \mathrm{~g}$ of DM increases the $\mathrm{n}-3$ fatty acid milk content (5-fold) and RA and VA levels ( $>3$-fold) without a concomitant increase in trans-10 C18:1 or trans-10 cis-12 C18:2 FA. Supplementation of extruded linseed also decreases by about 15 to $30 \%$ the contents of C12:0, C14:0, and C16:0, which are potentially hypercholesterolemic in humans. Furthermore, changes in FA profile of milk are maintained for at least 2 mo and no shift in the rumen biohydrogenation pathways occur. Acceptability of enriched cheeses was similar to that of cheeses made with milk from ewes fed a conventional diet. Because the processing of milk into cheese does not substantially alter the FA profile, the most practical approach for achieving cheeses with functional properties would consist of modifying the ration of these animals.

\section{ACKNOWLEDGMENTS}

This work was supported by the Ministerio de Ciencia e Innovación (projects AGL2008-04805-C02-01 and Consolider CSD2007-063), Comunidad Autónoma de Madrid (project S-505/AGR-0153) and Lodyn S.L. We thank A. García, J. C. Rodríguez (Ciudad Real, Spain), J. Romero (Talavera de la Reina, Spain), V. Rodríguez-Pino, and M. J. Jiménez (Madrid, Spain) for their assistance in this study.

\section{REFERENCES}

Akraim, F., M. C. Nicot, P. Juaneda, and F. Enjalbert. 2007. Conjugated linolenic acid (CLnA), conjugated linoleic acid (CLA) and other biohydrogenation intermediates in plasma and milk fat cows fed raw or extruded linseed. Animal 1:835-843.

AOAC. 1990. Official Methods of Analysis. 15th ed. Association of Official Analytical Chemists, Arlington, VA.

Bauman, D. E., A. L. Lock, B. A. Corl, C. Ip, A. M. Salter, and P. W. Parodi. 2006. Milk fatty acids and human health: Potential role of conjugated linoleic acid and trans fatty acids. Pages 523-555 in Ruminant Physiology: Digestion, Metabolism and Impact of Nutrition on Gene Expression, Immunology and Stress. K. Sjersen, T. Hvelplund, and M. O. Nielsen, ed. Wageningen Academic Publishers, Wageningen, the Netherlands.

Bell, J. A., J. M. Griinari, and J. J. Kennelly. 2006. Effect of safflower oil, flaxseed oil, monensin, and vitamin $\mathrm{E}$ on concentration of conjugated linoleic acid in bovine milk fat. J. Dairy Sci. 89:733748.

Bu, D. P., J. Q. Wang, T. R. Dhiman, and S. J. Liu. 2007. Effectiveness of oils rich in linoleic and linolenic acids to enhance conjugated linoleic acid in milk from dairy cows. J. Dairy Sci. 90:998-1007.

Chardigny, J. M., F. Destaillats, C. Malpuech-Brugere, J. Moulin, D. E. Bauman, A. L. Lock, D. M. Barbano, R. P. Mensink, J. B. Bezelgues, P. Chaumont, N. Combe, I. Cristiani, F. Joffre, J. B. German, F. Dionisi, Y. Boirie, and J. L. Sébédio. 2008. Do trans fatty acids from industrially produced sources and from natural sources have the same effect on cardiovascular disease risk factors in healthy subjects? Results of the trans Fatty Acids Collaboration (TRANSFACT) study. Am. J. Clin. Nutr. 87:558-566.

Collomb, M., R. Sieber, and U. Bütikofer. 2004. CLA isomers in milk fat from cows fed diets with high levels of unsaturated fatty acids. Lipids 39:355-364.

Da Silva, D. C., G. T. Santos, A. F. Branco, J. C. Damasceno, R. Kazama, M. Matsushita, J. A. Horst, W. B. R. Dos Santos, and H. V. Petit. 2007. Production performance and milk composition of dairy cows fed whole or ground flaxseed with or without monensin. J. Dairy Sci. 90:2928-2936. 
Deaville, E. R., D. I. Givens, and J. S. Blake. 2004. Dietary supplements of whole linseed and vitamin $\mathrm{E}$ to increase levels of $\alpha$-linolenic acid and vitamin E in bovine milk. Anim. Res. 53:3-12.

Destaillats, F., J. P. Trottier, J. M. G. Galvez, and P. Angers. 2005 Analysis of $\alpha$-linolenic acid biohydrogenation intermediates in milk fat with emphasis on conjugated linoleic acid. J. Dairy Sci. 88:3231-3239.

EFSA. 2005. Opinion of the scientific panel on dietetic products, nutrition and allergies on a request from the Commission related to nutrition claims concerning omega- 3 fatty acids, monounsaturated fat, polyunsaturated fat and unsaturated fat. EFSA J. 253:1-29.

Gómez-Cortés, P., G. Hervás, A. R. Mantecón, M. Juárez, M. A. de la Fuente, and P. Frutos. 2008. Milk production, CLA content and in vitro ruminal fermentation in response to high levels of soybean oil in dairy ewe diet. J. Dairy Sci. 91:1560-1569.

Gonthier, C., A. F. Mustafa, D. R. Ouellet, P. Y. Chouinard, R Berthiaume, and H. V. Petit. 2005. Feeding micronized and extruded flaxseed to dairy cows: Effects on blood parameters and milk fatty acid composition. J. Dairy Sci. 88:748-756.

Hervás, G., P. Luna, A. R. Mantecón, N. Castañares, M. A. de la Fuente, M. Juárez, and P. Frutos. 2008. Effect of sunflower oil in the diet of sheep on milk production, fatty acid profile and rumen fermentation. J. Dairy Res. 75:399-405.

IDF. 1987. Sensory Evaluation of Dairy Products. FIL-IDF standard no 99A. Brussels, Belgium.

ISO-IDF. 2002. Milk Fat. Determination of the Fatty Acid Composition by Gas-Liquid Chromatography. International Standard ISO 15885-IDF 184:2002 (E)

Loor, J. J., A. Ferlay, A. Ollier, K. Ueda, M. Doreau, and Y. Chilliard. 2005a. High-concentrate diets and polyunsaturated oils alter trans and conjugated isomers in bovine rumen, blood, and milk. J. Dairy Sci. 88:3986-3999.

Loor, J. J., A. Ferlay, A. Ollier, K. Ueda, M. Doreau, and Y. Chilliard 2005b. Relationship among trans and conjugated fatty acids and bovine milk fat yield due to dietary concentrate and linseed oil. J. Dairy Sci. 88:726-740.

Loor, J. J., K. Ueda, A. Ferlay, Y. Chilliard, and M. Doreau. 2004. Biohydrogenation, duodenal flow, and intestinal digestibility of trans fatty acids and conjugated linoleic acids in response to dietary forage:concentrate ratio and linseed oil in dairy cows. J. Dairy Sci. 87:2472-2485.

Luna, P., A. Bach, M. Juárez, and M. A. de la Fuente. 2008a. Influence of diets rich in flax seed and sunflower oil on the fatty acid composition of ewes' milk fat especially on the content of conjugated linoleic acid, n-3 and n-6 fatty acids. Int. Dairy J 18:99-107.

Luna, P., A. Bach, M. Juárez, and M. A. de la Fuente. 2008b. Effect of a diet enriched in whole linseed and sunflower oil on goat milk fatty acid composition and conjugated linoleic acid isomer profile. J. Dairy Sci. 91:20-28.

Luna, P., J. Fontecha, M. Juárez, and M. A. de la Fuente. 2005. Changes in the milk and cheese fat composition of ewes fed commercial supplements containing linseed with special reference to the CLA content and isomer composition. Lipids 40:445-454.

Mele, M., A. Serra, G. Conte, A. Pollicardo, M. del Viva, and P. Secchiari. 2007. Whole extruded linseed in the diet of dairy ewes during early lactation: Effect on the fatty acid composition of milk and cheese. Ital. J. Anim. Sci. 6(Suppl. 1):560-562.

Nudda, A., M. A. McGuire, G. Battacone, and G. Pulina. 2005 Seasonal variation in conjugated linoleic acid and vaccenic acid in milk fat of sheep and its transfer to cheese and Ricotta. J. Dairy Sci. 88:1311-1319.

Palmquist, D. L. 2006. Milk fat: Origin of fatty acids and influence of nutritional factors thereon. Pages 43 to 92 in Advanced Dairy Chemistry, Vol. 2, Lipids. 3rd ed. P. F. Fox and P. L. H. McSweeney, ed. Springer, New York, NY.

Pulina, G., A. Nudda, G. Battacone, and A. Cannas. 2006. Effects of nutrition on the contents of fat, protein, somatic cells, aromatic compounds, and undesirable substances in sheep milk. Anim. Feed Sci. Technol. 131:255-291.

Sanz-Sampelayo, M. R., Y. Chilliard, P. Schmidely, and J. Boza. 2007. Influence of type of diet on the fat constituents of goat and sheep milk. Small Rumin. Res. 68:42-63.

Sinclair, L. A., A. L. Lock, R. Early, and D. E. Bauman. 2007. Effects of trans-10 cis-12 conjugated linoleic acid on ovine milk fat synthesis and cheese properties. J. Dairy Sci. 90:3326-3335.

Van Soest, P. J., J. B. Robertson, and B. A. Lewis. 1991. Methods for dietary fiber, neutral detergent fiber, and nonstarch polysaccharides in relation to animal nutrition. J. Dairy Sci. 74:3583-3597.

Wilde, P. F., and R. M. Dawson. 1966. The biohydrogenation of $\alpha$-linolenic acid and oleic acid by rumen microorganisms. Biochem. J. $98: 469-475$.

Zhang, R. H., A. F. Mustafa, and X. Zhao. 2006. Effects of feeding oilseeds rich in linoleic and linolenic fatty acids to lactating ewes on cheese yield and on fatty acid composition of milk and cheese. Anim. Feed Sci. Technol. 127:220-233. 